\title{
The Effect Of Education On The Well-Being Of Korean Women, 1980-2001
}

\author{
Namchul Lee, (E-mail: nclee@krivet.re.kr), Korea Research Institute, Korea
}

\begin{abstract}
This paper examines the relationship between education and the well-being of Korean women during the period 1980-2001. The past 19 years has seen dramatic changes in the well-being of women and in their economic status. A broad range of indicators are considered to capture changes in women's well-being, notably education, labor force participation, wages, employment, unemployment, and occupational distributions. This paper compares well-being experiences between male and female workers, focusing on labor market indicators. This study uses extremely rich nation-wide aggregate statistics for performing decompositions to explain the trends of Korean women's well-being and economic development. Our main finding is that from 1980 to 2001 the well-being of Korean women increased quite markedly.
\end{abstract}

\section{Introduction}

$T$

he past 19 years has seen a dramatic increase in female labor participation and educational attainment in South Korea. Also, women's well-being and economic structure has changed substantially. In this paper we aim to contribute to the reviewing literature and statistical data on this topic by studying changes over time in the relative occupational status of South Korean women. An analysis of trends of women's well-being cannot proceed without the specification of a set of indicators by which well-being may be measured. We use data from 1980 to 1998 to trace the relationships between economic development and several indicators of women's status: investment in education, labor force participation, wages, employment, and unemployment rates. One purpose of this paper is to document these important changes in the well-being of women since 1980. Another goal of this paper is to investigate a set of indicators for this purpose and present their usefulness in forming a more complete picture of changes in women's well-being trends than may be obtained elsewhere.

One contribution of this paper is to analyze both changes in indicators of well-being for women relative to men, changes in absolute levels for women over time, and to conduct these inquiries at a disaggregated as well as at an aggregate level. In Korea, in particular, the fertility rate and female labor force participation have been inversely related. Both the secular decline in the fertility rate and the secular increase in the labor force participation of women in Korea are seen as consequences of increased real wages and market work opportunities available to women. Also, the proportion of women who are divorced has increased, while the proportion of those who are fertile has declined. For all ages and education groups, we obtain substantial evidence of rising gender equality in well-being, notably labor force participation, wages, and occupational distributions. The gender wage gap is declining, but so too is the magnitude of any real wage increases for women. A treatment of women's labor force activity has to include considerations of fertility, marriage, divorce, education, the distribution of family earnings, and male and female wage differentials. The first step is to describe briefly important economic development background, the decline in fertility, the increase of divorce, the rising trend of women becoming the head of the household, and the expansion of educational attainment. These factors are examined to assess their impact on employment and labor force participation. The second step is to analyze workers by occupation and gender between 1980 and 2001. Lastly, developments of the cost of labor, i. e. wages, earnings differentials, employment, and unemployment are presented. 


\section{Changes in Women's Socioeconomic Background}

\section{Fertility}

Economists have been interested in the question of why fertility rates always decline when a country goes through the process of sustained development. The traditional allocation of time provides a conceptual framework that suggests that in industrialized countries, in particular, fertility and female labor force participation will likely be inversely related (Shapiro and Shaw, 1983). However, Becker and Lewis (1974) and Willis (1973) have provided explanations of this phenomenon from different perspectives. They use the concept of the household production function, focusing on the importance of time as an input in household production processes and the relevance of the quantity and quality of childbirth and childcare facilities in the fertility decision. Easterlin and Crimmins (1985) explained urbanization and industrialization as the factors responsible for the decline in desired fertility. We suggest that fertility decline is culture-specific in countries and many factors affect fertility such as preferences and the desired number of children.

During the period 1961-95, Korea experienced the biggest change in the fertility rate. While fertility has been declining in less development countries, there has been a rapid narrowing of the gap in mortality rates between developed countries (World Bank, 1997). There are several factors for the decline in fertility rates. The primary reason is undoubtedly the improvement in health conditions through the Third World. The second factor is the greater number and reliability of contraceptive devices, as well as greater social acceptance of family planning. A third factor that has been given much attention by economists is the growing "price" of children. The price or cost of a child for the family is the direct cost of education, clothing, food, and opportunity cost of the wife's time if she does not work. The relative price of time-intensive activities such as raising children has grown considerably, causing families to consciously cut back on the number of children they desire. Females in developing countries are faced with competing demands of reproduction and workforce roles. The relationship between work and fertility is complex. Female workers may choose to limit childbearing so they can work and earn income, as having a child may affect the type of work they can do, where they can work or the hours they can work. Higher wages are associated with lower fertility rates. More-educated women who can command relatively high wage rates in the labor market tend to have fewer children than less-educated women for whom wages are low. Child rearing is a highly -intensive activity, and thus the opportunity cost of children-the income sacrificed by not being in the labor market-is higher for more educated women than for those who are less- educated.

In Korea, the birth rate has been falling rapidly over the last few decades to a level similar to that of the developed countries from 6.0 per fertile woman in 1960 to 1.3 per fertile woman in 2001. This low birth rate means married women will spend less time on child care, increasing their likelihood of participation in the labor force. It has facilitated growth in the participation of married women in the labor force by providing substitutes for the wife's time at home, and it has lowered the costs of fertility control. In this context, then both the secular decline in fertility and the secular increase in the labor force attachment of married women in Korea are seen as consequences of increased real wages and market work opportunities available to women. On the other hand, the decline in the birth rate has changed the age composition of the population. More specifically, the proportion of the population younger than 15 years has decreased dramatically. As a whole, the female number of the population younger than 15 years changed from 5,356 (thousand) in 1990 to 4,876 (thousand) by 1995 (National Statistical Office, 1999).

\section{Marriage and Divorce}

In 1980, there were over 403,031 instances of marriage; in 2001, the number decreased to 320,063 . Considering that, between 1980 and 2000, the total Korean population increased by over 8.7 million(census enumeration), the fall in the number of marriages is a departure from the past trend of more or less parallel increases in the numbers of total population and marriages. By comparison, the number of divorces in 2001 was well over 111,352 more than that in 1980, more than a four-fold increase in the divorce rate during the 22 year period. Table 1 indicates marriages, divorces, and average age at the first marriage during the period 1980-2001. Perhaps to be expected given the trends below of marriages and divorces, the average age of first marriage increased by more than a year for both males and females. This was true for the whole country and for the urban population. For the country as a whole, the average age for males increased from 27.3 years in 1985 to 29.6 years by 2001 while the average for females increased from 24.5 years to 26.8 years by 2001 . 
Table 1: Marriage, Divorce Rate, 1980-2001

\begin{tabular}{|c|c|c|c|c|c|c|}
\hline \multirow{2}{*}{ Year } & \multirow{2}{*}{ Marriage } & \multirow{2}{*}{ Divorce } & \multirow{2}{*}{$\begin{array}{c}\text { Divorce } \\
\text { Rate }\end{array}$} & \multicolumn{2}{|c|}{ Average age at the first marriage } \\
\cline { 5 - 7 } & & & Female & Male & Difference \\
\hline $\mathbf{1 9 8 0}$ & 403,031 & 23,662 & 0.6 & - & - & - \\
\hline $\mathbf{1 9 8 5}$ & 376,847 & 38,838 & 1.0 & 24.5 & 27.3 & 2.8 \\
\hline $\mathbf{1 9 9 0}$ & 404,354 & 45,022 & 1.1 & 24.9 & 27.9 & 3.0 \\
\hline $\mathbf{1 9 9 5}$ & 399,829 & 68,078 & 1.5 & 25.4 & 28.5 & 3.1 \\
\hline $\mathbf{1 9 9 8}$ & 366,647 & 123,731 & 2.6 & 26.2 & 29.0 & 2.8 \\
\hline $\mathbf{2 0 0 1}$ & 320,063 & 135,014 & 2.8 & 26.8 & 29.6 & 2.8 \\
\hline
\end{tabular}

Source: National Statistical Office (various years), Annual Report on the Vital Statistics. Note: "-" missing data.

This trend is generally attributed to an increasing difficulty encountered by rural youths in finding suitable mates from among a decreasing pool of their chronological peers. Between 1980 and 2001 divorce rates accelerated a factor of $0.6 \%$, using 1980 as the base year, to a factor of $2.8 \%$ by 2001 . Therefore, the number of divorces more than five times during the same period.

\section{Education and Economic Development}

\section{Educational Enrollment}

There is certainly a good deal of evidence to support the proposition that women are now entering the labor market with far better qualifications than their mothers and grandmothers had. The level of educational enrollment of women of school-leaving age has been steadily improving over recent decades, to such an extent that in a number of countries they are now significantly better qualified than men on leaving school. Before exploring the educational enrollment level of the working female labor force, it might be advantageous to explain briefly how the whole population in Korea can be classified with respect to educational enrollment. There has a notable decline in the educational enrollment gap between men and women in Korea. During the period 1980-2001, the average educational level of both men and women rose. Table 2 presents the school enrollment ratio by education and gender during the period 1980-2001. With respect to education, we can observe a continuous increase in the proportion of men and women attending school. Between 1980 and 2001 the high school enrollment ratios for males increased from 70.3 percent to 94.7 percent, while for females it increased from 56.2 percent to 94.7 percent. The higher education enrollment ratios for females increased from 22.9 percent to 62.6 percent, while for males it increased from 50.2 percent to 101.6 percent during the period 1985-2001. In particular, the proportion of female college graduates in the workforce more than doubled during this period, but it was still lower than the proportion for males in 2001.

Better-educated individuals have, on average, higher rates of labor force participation and higher earnings than those with lower qualifications. Labor force activity rises with educational enrollment. The relationship is especially strong in the case of women, while the relationship is slightly weaker for men because their participation rates approach universal levels. However, even in the case of men, those with less than an upper secondary education have markedly lower participation rates any other group.

With respect to education, we can observe a continuous increase in the proportion of men and women attending school. In Korea, in case studies of the labor force participation of females, schooling is probably the most consistently effective explanatory variable. In Korea, there has been a steep rise of participation with schooling and changes in the distribution of females by completed years of schooling accounts for significant changes in the labor force participation rate. The expansion of female education in Korea is also reflected in the labor force. Between 1982 and 1996, the proportion of high school graduates and college graduates in the economically active population increased dramatically for women. 
Table 2: School Enrollment Rates by School Level, 1980-200

\begin{tabular}{|c|c|c|c|c|c|c|c|c|}
\hline \multirow{2}{*}{ Year } & \multicolumn{2}{|c|}{ Elementary } & \multicolumn{2}{c|}{ Middle } & \multicolumn{2}{c|}{ High } & \multicolumn{2}{c|}{ Higher } \\
\cline { 2 - 9 } & Female & Male & Female & Male & Female & Male & Female & Male \\
\hline $\mathbf{1 9 8 0}$ & 103.7 & 102.1 & 92.5 & 97.5 & 56.2 & 70.3 & - & - \\
\hline $\mathbf{1 9 8 5}$ & 102.5 & 99.4 & 99.3 & 100 & 74.5 & 81.9 & 22.9 & 50.2 \\
\hline $\mathbf{1 9 9 0}$ & 100.1 & 99.6 & 98.2 & 98.6 & 83.8 & 90.5 & 23.9 & 50.0 \\
\hline $\mathbf{1 9 9 4}$ & 101.0 & 100 & 99.4 & 98.6 & 88.0 & 89.4 & 33.5 & 63.2 \\
\hline $\mathbf{1 9 9 6}$ & 97.8 & 96.5 & 103.2 & 102.6 & 89.5 & 90.1 & 45.1 & 77.6 \\
\hline $\mathbf{1 9 9 7}$ & 98.9 & 98.4 & 101.3 & 100.8 & 94.3 & 95.0 & 50.9 & 85.7 \\
\hline $\mathbf{2 0 0 1}$ & 98.8 & 98.0 & 99.8 & 98.2 & 94.7 & 94.7 & 62.6 & 101.6 \\
\hline Change & -4.9 & -4.1 & 7.3 & 0.7 & 39.2 & 24.4 & 39.7 & 51.4 \\
\hline
\end{tabular}

Source: Ministry of Education and Korean Educational Development Institute (various years),

Educational Indicators in Korea.

Note: 1) Higher education includes junior vocational colleges, junior colleges, and teachers' colleges.

2) Using number of 18-21 age students instead of total student.

3) “-” missing data.

The increasing enrollment ratios of colleges reduce the labor supply of youths and exacerbate the effects of lower fertility rates. There have been some structural changes in the pattern of female undergraduate enrollment in various fields of study as shown Table 3. In 1985, at 4-year colleges and universities the combined female enrollment in humanities and social science stood at 40.2 percent of all female college and university students. By 2001, there had been a 7.9 percent increase in that figure to at 48.1 percent. In natural science, engineering, medicine and pharmacology, the combined female enrollment ratio for 1985 was 25.1 percent. This figure had risen to 31.7 percent by 2001 , showing a 6.6 percent increase. Female enrollment decreased in majors for the teaching profession by 14.7 percent from 1985 to 2001 . However, the percentage of female enrollment increased from 56.8 percent to 62.0 percent in this field. The fields where female enrollment ratios decreased by 0.7 between 1985 and 1998 included art and physical education. The past 17 years has seen a dramatic change in the pattern of female enrollment in social science by 12.6 percent. As may be seen in Table 3, recent enrollment data indicate a continuation of a general trend in which increasing numbers of women are majoring in nontraditional areas such as law, business, computer science, and engineering. Despite these changes, substantial differences remain. In 2001, the rate of obtaining bachelor's degrees in business fields increased three times for female students. The numbers of women majoring in medicine, dentistry, and engineering, however, remain small fractions of the numbers of men (Ministry of Education, 2002).

Table 3: Undergraduates by Major Field of Study, 1985-2001

\begin{tabular}{|l|c|c|c|c|c|c|c|c|c|c|}
\hline \multicolumn{1}{|c|}{ Field } & $\mathbf{1 9 8 5}(\mathbf{A})$ & \multicolumn{2}{|c|}{$\mathbf{1 9 9 0}(\mathbf{B})$} & \multicolumn{2}{|c|}{$\mathbf{1 9 9 5}(\mathbf{C})$} & \multicolumn{2}{|c|}{$\mathbf{2 0 0 1}(\mathbf{D})$} & \multicolumn{2}{c|}{ Change (D-A) } \\
\hline & $\boldsymbol{F}$ & $\mathbf{\%}$ of $\boldsymbol{F}$ & $\boldsymbol{F}$ & $\mathbf{\%}$ of $\boldsymbol{F}$ & $\boldsymbol{F}$ & $\mathbf{\%}$ of $\boldsymbol{F}$ & $\boldsymbol{F}$ & $\mathbf{\%}$ of $\boldsymbol{F}$ & $\boldsymbol{F}$ & $\boldsymbol{\%}$ of $\boldsymbol{F}$ \\
\hline Humanities & 25.6 & 42.6 & 24.5 & 46.5 & 22.9 & 52.1 & 20.9 & 56.5 & -4.7 & 13.9 \\
\hline Social Science & 14.6 & 14.2 & 17.2 & 17.7 & 20.7 & 25.5 & 27.2 & 36.6 & 12.6 & 22.4 \\
\hline Natural Science & 19.9 & 14.8 & 27.0 & 19.1 & 28.6 & 20.7 & 26.9 & 22.5 & 7.0 & 7.7 \\
\hline $\begin{array}{l}\text { Medicine \& } \\
\text { Pharmacology }\end{array}$ & 5.2 & 62.0 & 4.8 & 35.4 & 4.6 & 38.8 & 4.8 & 48.3 & -0.4 & -13.7 \\
\hline $\begin{array}{l}\text { Art \& Physical } \\
\text { Education }\end{array}$ & 13.2 & 32.8 & 13.2 & 56.8 & 12.5 & 55.7 & 13.3 & 55.6 & -0.1 & 22.8 \\
\hline $\begin{array}{l}\text { Teaching } \\
\text { Profession }\end{array}$ & 21.5 & 56.8 & 13.2 & 57.6 & 10.8 & 65.4 & 6.8 & 62.0 & -14.7 & 5.2 \\
\hline
\end{tabular}

Source: Ministry of Education (various years), Statistical Yearbook of Education.

Notes: 1). F; female, M; male, Junior Teachers' Colleges excluded.

2). Author calculation from Ministry of Education data. 


\section{Educational Attainment}

Before exploring the educational attainment level of the working female labor force it might be advantageous to give a brief on how the whole population in Korea can be classified with respect to educational attainment. Table 4 shows that there has been a substantial increase in educational attainment of successive female cohorts in Korea. There has a notable narrowing in the educational attainment gap between men and women in Korea.

During the period 1980-2000, the average educational level of both men and women rose. In 1980 the educational attainment ratio had reached 8.67 percent and 6.63 percent for males and females, respectively. In 2000 , the educational attainment ratio had increased to 10.2 percent and 9.8 percent for males and females, respectively. The average of male and female educational attainment ratios differentials decreased from 2.04 percentage points to 0.4 percentage points between 1980 and 2000 (National Statistical Office, 1999, 2002). At all ages, the smallest gap between the genders ( 0.50 percentage points) is for the group aged 6-19 and the largest gap (3.06 percentage points) is for those in the 40-49 age group in 1980. However, in 2000, the smallest gap between the genders $(0.2$ percentage points) is for those aged 20-29 and the largest gap (3.4 percentage points) is for those aged over 50.

A long-term trend with respect to educational attainment is that each generation completes more years of schooling than its predecessors. Between 1980 and 2000, the average educational attainment ratio has increased 1.53 percentage and 3.17 percentage for males and females, respectively. At all age levels, the smallest change between genders ( 0.1 percentage points) is for the 6-19 age group for males and the largest change between the sexes (4.55 percentage points) is for those aged 40-49 for females during the same period. There are fairly consistent differences in educational attainment between males and females. In general, men are more likely to have completed a basic education than women.

Table 4: Educational Attainment by Age and Sex, 1980-2000

\begin{tabular}{|c|c|c|c|c|c|c|c|}
\hline & & Average & 6-19 age & $20-29$ age & $30-39$ age & 40-49 age & Age $50+$ \\
\hline \multirow[t]{3}{*}{1980} & Difference & 2.04 & 0.50 & 0.89 & 2.09 & 3.06 & 2.78 \\
\hline & Male & 8.67 & 6.60 & 10.33 & 10.19 & 9.01 & 5.03 \\
\hline & Female & 6.63 & 6.10 & 9.44 & 8.10 & 5.95 & 2.25 \\
\hline \multirow[t]{3}{*}{1985} & Difference & 2.08 & 0.00 & 0.73 & 1.65 & 2.74 & 3.41 \\
\hline & Male & 9.66 & 6.71 & 11.34 & 10.93 & 9.88 & 6.49 \\
\hline & Female & 7.58 & 6.71 & 10.61 & 9.28 & 7.14 & 3.08 \\
\hline \multirow[t]{3}{*}{1990} & Difference & 1.97 & 0.09 & 0.45 & 1.41 & 2.29 & 3.64 \\
\hline & Male & 10.55 & 7.70 & 12.26 & 11.78 & 10.64 & 7.56 \\
\hline & Female & 8.58 & 7.79 & 11.81 & 10.37 & 8.35 & 3.92 \\
\hline \multirow[t]{3}{*}{1995} & Difference & 1.83 & 0.4 & 0.02 & 1.13 & 1.84 & 3.73 \\
\hline & Male & 11.09 & 6.61 & 12.65 & 12.62 & 11.31 & 8.45 \\
\hline & Female & 9.26 & 7.01 & 12.67 & 11.49 & 9.47 & 4.72 \\
\hline \multirow[t]{3}{*}{2000} & Difference & 1.7 & 0.7 & 0.2 & 0.7 & 1.5 & 3.4 \\
\hline & Male & 11.5 & 5.3 & 13.0 & 13.2 & 12.0 & 9.2 \\
\hline & Female & 9.8 & 6.0 & 13.2 & 12.5 & 10.5 & 5.5 \\
\hline \multirow{2}{*}{$\begin{array}{c}\text { Change (1980- } \\
\text { 2000) }\end{array}$} & Male & 1.53 & -1.3 & 2.67 & 3.01 & 2.99 & 4,17 \\
\hline & Female & 3.17 & -0.1 & 3.76 & 4.40 & 4.55 & 3.25 \\
\hline
\end{tabular}

Source: National Statistical Office (1999, 2002), Population \& Housing Census.

Note: Author calculation from National Statistical Office data. 


\section{Korean Labor Market}

\section{Trends in Labor Force Participation}

The labor force participation decision is based on a comparison of the market wage with the reservation wage (See Appendix). Thus, the increase in the labor force participation rates can be attributed not only to a rise in the market wage, but also to a decline in female reservation wages. The rise in the market wage, which increased female participation rates, also made childbearing a very expensive household activity. As a result, some of the causation runs in the opposite direction. Women participate more not because they have fewer children, rather, they have fewer children because the rising wage induces them to reduce their time in the household sector and enter the labor market. Labor force participation of females is also influenced by technological changes in the process of household production. There have been remarkable time-saving technological advances in household production. As a result, the amount of time required to produce many household commodities has been cut drastically, freeing up spare time for leisure activities and for work in the labor market. The technological advances in household production probably reduced the gap in marginal need for specialization, and was less of a contributing factor to the increase in female labor force participation.

The proportion of labor force participation of Korean women is similar to that of women in many industrialized countries. As of 1996, $45 \%$ of all women (15 years of age and older) were participating in the paid economy. This figure is somewhat lower than the comparable figures in the United States and some European countries, such as Sweden, but similar to figures in other countries, such as Germany and France (OECD, 1998). The majority of employed women (more than $60 \%$ ) hold full-time jobs.

Table 5 indicates the participation rate by type of household and sex during the period 1985-96. The trend toward a higher proportion of working women affected both the farm households and non- farm households. The female participation rate of farm households grew strongly from 52.9 percent in 1985 to 68.2 percent in 2001, while the male participation rate of non-farm household grew weakly, from 72.3 percent in 1985 to 73.0 percent in 2001. Table 5 illustrates the reasons why potential workers do not join the labor market from non-farm households. It is clear that school attendance is the primary reason for non-participation by males, while working at home is the main reason for females. However, rates for males working at home and for females attending school have increased slightly over time. Data are for the standard measure of labor force participation based on a monthly survey of employment status. The increase in female labor force participation rates has been very slow over the past 19 years in spite of the decline in female fertility rates. In 1985 the labor force participation of women was 38.8 percent for non-farm households, 52.9 percent for farm households; the corresponding figures for men were 72.3 percent and 72.5 percent, respectively. Table 5 shows that labor force participation rates for females are much higher for farm households than non-farm households, while there is little difference between the two types of households for men. It appears that female participation rates have increased faster for both types of households since 2001, but this is too short a period to predict future trends.

Table 5: Participation Rate by Type of Household and Sex, 1985-2001

(unit: \%)

\begin{tabular}{|c|c|c|c|c|c|c|c|}
\hline & Sex & $\mathbf{1 9 8 5}(\mathbf{A})$ & $\mathbf{1 9 9 0}(\mathbf{B})$ & $\mathbf{1 9 9 2}(\mathbf{C})$ & $\mathbf{1 9 9 4}(\mathbf{D})$ & $\mathbf{2 0 0 1}(\mathbf{E})$ & Change (E-A) \\
\hline Whole & Male & 76.4 & 74.0 & 75.5 & 76.4 & 73.6 & -2.8 \\
\hline & Female & 42.8 & 47.0 & 47.3 & 47.9 & 48.8 & 6.0 \\
\hline Non-farm & Male & 72.3 & 73.9 & 75.2 & 76.1 & 73.0 & 6.7 \\
\hline & Female & 38.8 & 44.1 & 44.4 & 45.4 & 46.8 & 8.0 \\
\hline Farm & Male & 72.5 & 74.5 & 77.4 & 78.7 & 80.3 & 7.8 \\
\hline & Female & 52.9 & 61.8 & 64.5 & 66.2 & 68.1 & 15.2 \\
\hline
\end{tabular}

Source: National Statistical Office (various years), Annual Report on the Economically Active Population Survey. 
The most striking fact about male labor participation is the decreasing proportion of time that males spend at work throughout the whole country. This decline is due to several factors. First, younger persons have stayed at school longer and increasingly continued their education after leaving school. Second, males have been retiring, either wholly or partially, at younger ages. The proportion of females in the labor force appears to be greatly affected by employment opportunity. The greater the extent of employment growth in a country, the higher the percentage of females in the work force. The proportion is also affected by the relative size of the retired population. The higher the proportion of the retired population, the smaller the proportion of adults in the workforce. The percentage of women having children 18 years or younger at home in the labor force increased substantially in the country during the 1980 s, producing a very uniformly high rate of participation among the provinces in 1990s. Recently, labor force participation rates of women rose in most of the industrialized countries, continuing longer-term though less apparent trends. These trends are due mainly to the growth of labor force participation of married women. Females aged 65 and over in Korea are high to be part of the labor force compared with Japan, Singapore, France, and U.S., while the total participation rate for women in the labor force is lower than that of the U.S., Canada, and Japan. In Japan, Canada, and U. S., labor force participation rates of women 50 percent, while the participation rate of Korea women was 48.7 percent by 1996 ( OECD, 1998).

Table 6: Participation Rate by Gender and Marital Status, 1980-2001

\begin{tabular}{|c|c|c|c|}
\hline \multicolumn{2}{|c|}{} & \multicolumn{2}{|c|}{ (unit: \%) } \\
\cline { 3 - 4 } \multicolumn{2}{|c|}{} & Marticipation Rate \\
\hline \multirow{2}{*}{$\mathbf{1 9 8 0}$} & Female & 40.0 & Single \\
\cline { 2 - 4 } & Male & 88.3 & 50.8 \\
\hline \multirow{2}{*}{$\mathbf{1 9 8 5}$} & Female & 41.0 & 52.4 \\
\cline { 2 - 4 } & Male & 86.8 & 44.7 \\
\hline \multirow{2}{*}{$\mathbf{1 9 9 0}$} & Female & 47.2 & 44.6 \\
\cline { 2 - 4 } & Male & 88.4 & 46.5 \\
\hline \multirow{2}{*}{$\mathbf{1 9 9 5}$} & Female & 47.6 & 74.0 \\
\cline { 2 - 4 } & Male & 88.8 & 50.4 \\
\hline \multirow{2}{*}{$\mathbf{2 0 0 1}$} & Female & 49.0 & 49.6 \\
\cline { 2 - 4 } & Male & 83.8 & 48.1 \\
\hline $\begin{array}{c}\text { Change } \\
(\mathbf{1 9 8 0} \\
\mathbf{- 2 0 0 1 )}\end{array}$ & Female & 9.0 & 50.2 \\
\cline { 2 - 4 } & Male & -4.5 & -2.7 \\
\hline
\end{tabular}

Source: National Statistical Office (various years), Annual Report on the Economically Active Population Survey.

Indeed, labor force rates of single women declined, if women of school ages are included, and grew little beyond school ages. In the past, the participation rate of single women was much higher than the rate of married women. However, between 1980 and 2001, labor force participation rates of married women have increased from 40.0 percent to 49.0 percent, while labor force participation rates of single women have decreased from 50.8 percent to 48.1 percent in Korea. Why did this change occur? On the supply side, more married women may have been willing to enter the labor market because they were having fewer children; because their time spent producing such household goods as food, or spending time on activities such as cleaning was falling thanks to new household technologies such as washing machines, dishwashers, vacuum cleaners, and prepared foods; because their conditions, hours, and status of work were improving; and because their preferences for work may have changed. On the demand side, firms may have been more willing to hire women because of the clerical and sales sectors; the development of technologies that allowed firms to substitute the labor of women for that of men; the growth of formal education that could replace on-the-job-training; and changes in the tastes of employers and their male employees or reduced discrimination. 
One of the recent trends showing that continuity of participation is growing in Korea is that recently, more and more women take much less time out of the labor market for childcare. Thus in the most recent decade, the fastest labor force growth is observable among mothers of small children. To some extent, the greater continuity of market employment was achieved by a reduction in fertility. The average labor force rate of married women grew from 40 percent to 47.9 percent between 1980 and 2001. It is important to note that the preferred definition of labor force participation in this study is restricted to paid employment outside the home-a definition that makes choices between household and market activities unambiguous. This definition rules out the possibility of joint activity primarily in rural households. A relatively large proportion of Korea women are still household workers and farm workers, but these groups are declining in importance, while employment outside the household is growing. The growth of married womens' labor market activities have, however, been accompanied by declines in fertility and increases in divorce rates. Although fertility has shown a long-term downward trend in Korea since 1980, divorce rates accelerated from a base factor of 1.0, to a factor of 2.6 between 1989 and 1998 in Korea.

A couple of interesting facts can be observed when one breaks down participation by age. First, the number of females in the economically active population is relatively small for those between the ages of fifteen and nineteen, i. e. the age interval for peak school attendance. Note that the number of female and male workers drops significantly during their school attending years. In addition, the size of the economically active population aged fifteen to twenty-four is larger for females than males. This might be a result of the fact that males advance to a higher level of education than females and therefore they enter the labor market later. Moreover, men must serve military service for an average of two and half years while women are exempt.

Table 7: Labor Force Participation Rates by Level of Education, 1985-2001

\begin{tabular}{|l|c|c|c|c|c|c|c|c|}
\hline & \multicolumn{2}{|c|}{ (unit: \%) } \\
\hline & $\begin{array}{c}\text { Under } \\
\text { Middle }\end{array}$ & $\begin{array}{c}\text { High } \\
\text { School }\end{array}$ & $\begin{array}{c}\text { Junior } \\
\text { College }\end{array}$ & $\begin{array}{c}\text { College } \\
\text { or Over }\end{array}$ & $\begin{array}{c}\text { Under } \\
\text { Middle }\end{array}$ & $\begin{array}{c}\text { High } \\
\text { School }\end{array}$ & $\begin{array}{c}\text { Junior } \\
\text { College }\end{array}$ & $\begin{array}{c}\text { College or } \\
\text { higher }\end{array}$ \\
\hline $\mathbf{1 9 8 5}$ & 39.5 & 42.1 & 60.8 & 46.3 & 61.1 & 77.1 & 89.3 & 93.5 \\
\hline $\mathbf{1 9 9 0}$ & 45.6 & 47.5 & 66.1 & 53.1 & 63.2 & 80.0 & 93.4 & 93.2 \\
\hline $\mathbf{1 9 9 5}$ & 44.6 & 50.2 & 63.5 & 57.9 & 62.3 & 81.2 & 94.2 & 93.9 \\
\hline $\mathbf{1 9 9 7}$ & 44.4 & 52.0 & 68.1 & 61.0 & 60.5 & 81.0 & 94.6 & 91.8 \\
\hline $\mathbf{1 9 9 8}$ & 42.4 & 48.4 & 65.0 & 56.7 & 58.4 & 80.0 & 93.3 & 90.6 \\
\hline $\mathbf{2 0 0 1}$ & 43.2 & 50.4 & 65.6 & 58.1 & 56.9 & 77.6 & 91.3 & 87.7 \\
\hline $\begin{array}{c}\text { Change } \\
(\mathbf{1 9 8 5 - 2 0 0 1 )}\end{array}$ & 3.7 & 8.3 & 4.8 & 11.8 & -4.2 & 0.5 & 2.0 & -5.6 \\
\hline
\end{tabular}

Source: National Statistical Office (1990, 1999, 2002), Economically Active Population Survey.

In Table 7, the main findings are follows. During the period 1980-94, the female labor force participation rates of Korea increased substantially regardless of level of education (National Statistical Office, 1980 and 1994). The female labor force participation rates at junior college level is higher than that at any other level of education during the same period. Before (1997) and after (1998) Korea's economic crisis, one of the most noticeable changes was the sharply decreasing female labor force participation rates from 61.0 percent to 56.7 percent for those with a college level or higher education. The male labor force participation rates at college level decreased from 91.8 percent to 90.6 percent during the same period. The male labor force participation rates show evidence that the economic crisis affected female workers more than male workers. The past 13years have seen a dramatic change in the pattern of female participation in college or over by 11.8 .

\section{Earning Differentials}

One of the interesting features of the female and male wage differential structure in Korea is that wage differentials are fairly large compared to that of developed countries. Authors suggest that differences in productivity-related characteristics explain 68.5 percent of the gap, with 31.5 percent attributable to the labor market discrimination in 1981 (Park, 1984). There are two separate reasons for earnings differential. One reason is that men are proportionately over-represented in high-wage professional, managerial, and craft occupations, while 
women are over-represented in low-wage clerical and service occupations. A second reason is that even within a given occupation, women tend to less than men (Ministry of Labor, 1998). The Gini Coefficient in 1981 was 0.355, which continuously decreased to 0.2830 in 1997 . However, The Gini Coefficient increased to 0.3157 after the financial crisis in 1998. The female to male wage ratio for workers increased from $0.43 \%$ in 1977 to $0.60 \%$ in 1996. For the period 1977-86, average wages for females are less than half the wages paid to males. Although increased wage inequality among men during the past two decades has received more attention, the growth in women's wages has been equally remarkable. The earnings gap should continue to narrow as women work more hours in the week, spend more years at paid work in their lifetimes, continue to increase their educational investment, widen their occupational choices, and equal opportunity becomes a reality.

Table 8: Wage Differentials Level by Educational Attainment and Sex, 1995 - 1998

\begin{tabular}{|l|c|c|c|c|}
\multicolumn{5}{|c|}{ (unit: \%) } \\
\hline & $\begin{array}{c}\text { Middle school } \\
\text { under }\end{array}$ & High school & Junior college & University \\
\hline $\mathbf{1 9 9 5}$ & 56.1 & 63.1 & 68.9 & 71.7 \\
\hline $\mathbf{1 9 9 7}$ & 57.9 & 65.8 & 69.1 & 74.9 \\
\hline $\mathbf{1 9 9 8}$ & 57.6 & 66.9 & 70.9 & 74.3 \\
\hline
\end{tabular}

Source: Ministry of Labor (various years), Survey Report on Wage Structure.

Note: Wage differential level of middle school; 100.

Table 8 shows the wage differential by educational attainment and sex. The wage differential by educational attainment and sex had reached 57.6 percent and 74.3 percent for both middle school and university level by 1998 , respectively. The wage differential in higher education level is relatively narrow, while the wage differential in lower education is relatively wide. An increase in female wage rates and the narrowed gap between male and female wage rates may have induced a substitution effect between housework and or leisure and market work supported by higher technical standards of home production factors. If this was not offset by the income effects from the husband's earnings, it could also explain the higher labor force participation rates of married women. The level of female education is particularly important because it affects male-female earnings differentials. This is displayed in Table 8, which shows a clear positive relationship between educational attainment and female/male earnings ratios.

It also shows that the female/male earnings ratios changed little over the last decade for workers with less than a college education, while the ratios for college graduates only increased slightly during the 1980s. It is striking that the earnings ratio of any education group by itself is much higher than that of the workforce as a whole. While for the elementary school group, direct data are not available in the report on the occupational wage survey, preliminary calculations using a sample of the occupational wage survey micro-data indicate that its earnings ratio is similar to that of the middle school group. From a simple arithmetic argument, one can infer that women are much more concentrated in lower earning, hence less educated, groups than men; this conclusion can be verified in Table 8. We use men's earnings as a "yardstick" to measure women's, and we say women's earnings are a percentage of men's. The earnings gap is the difference between this percentage ratio and 100 percent. The earnings ratio data are not uniform among all occupations. In some occupations females receive approximately equal, or even greater, compensation than their male co-workers in the same occupation. Occupations with higher earnings for women than men are the traditional (e.g. nursing) occupations for females.

\section{Employment}

Since the 1960s, the growth of the Korean economy has been driven by several industries. The 1970s were driven by labor-intensive light industries, the 1980s by capital-intensive heavy and chemical industries, and the 1990 s by high-tech assembly industries. Although unemployment rates have been higher among male workers than females since the economic crisis, the employment level for female workers declined more rapidly than that of male workers. Between 1997 and 1998, male employment declined by 510,000 (-4.1 percent), but female employment dropped by 602,000 ( -6.9 percent). Consequently, females' share of total employment declined by 2.8 percentage points. 
Table 9 shows employed persons by industry between 1980 and 2001. Interestingly, female employment increased relatively more in business, private, public services, and other industries, from 34.3 percent to 45.7 percent between 1980 and 2001. By contrast, the female employment decreased relatively more in manufacturing industries from, 39.1 percent to 36.0 percent during the same period.

Table 9: Employed Persons by Industry; 1980 and 2001

(unit: 1,000 , percent)

\begin{tabular}{|c|c|c|c|c|c|c|c|c|c|}
\hline & \multicolumn{3}{|c|}{$1980(\mathrm{~A})$} & \multicolumn{3}{|c|}{$2001(B)$} & \multicolumn{3}{|c|}{ Changes (B-A) } \\
\hline & Total & Female & $\begin{array}{c}\text { Share Of } \\
\text { Female }\end{array}$ & Total & Female & $\begin{array}{c}\text { Share Of } \\
\text { Female }\end{array}$ & Total & Female & $\begin{array}{c}\text { Share Of } \\
\text { Female }\end{array}$ \\
\hline $\begin{array}{l}\text { Agriculture, forestry \& } \\
\text { fishing }\end{array}$ & 4,654 & 2,034 & 43.7 & 2,193 & 1,036 & 47.2 & $-2,461$ & -998 & 3.5 \\
\hline $\begin{array}{l}\text { Mining \& } \\
\text { manufacturing }\end{array}$ & 3,079 & 1,166 & 37.9 & 4,219 & 1,511 & 35.8 & 1,140 & 345 & -2.1 \\
\hline Manufacturing & 2,955 & 1,155 & 39.1 & 4,199 & 1,511 & 36.0 & 1,244 & 356 & -3.1 \\
\hline $\begin{array}{l}\text { Social overhead capital } \\
\text { \& other services }\end{array}$ & 5,951 & 2,022 & 33.9 & 14,950 & 6,347 & 42.5 & 8,999 & 4,325 & 8.6 \\
\hline - Construction & 843 & 72 & 8.5 & 1,575 & 133 & 8.4 & 732 & 61 & -0.1 \\
\hline $\begin{array}{l}\text {-Wholesale, retail, } \\
\text { restaurants. \& hotels }\end{array}$ & 2,625 & 1,275 & 48.6 & 5,820 & 3,161 & 54.3 & 3,195 & 1,886 & 5.7 \\
\hline $\begin{array}{l}\text { Electricity, transport, } \\
\text { storage, finance }\end{array}$ & 995 & 164 & 16.5 & 2,110 & 564 & 26.7 & 1,115 & 400 & 10.2 \\
\hline $\begin{array}{l}\text { Business, private } \& \\
\text { public Services \& others }\end{array}$ & 1,489 & 511 & 34.3 & 5,444 & 2,489 & 45.7 & 3,955 & 1,978 & 11.4 \\
\hline
\end{tabular}

Source: National Statistics Office of Korea (various years), Annual Report on the Economically Active Population Survey.

Note: Author calculation from National Statistics Office data.

Table 10 also presents the proportion of female employment to total employment for each occupation. Historically, females have been "crowded" into a few occupations. In 1997 three most prevalent occupations for females were, in order of magnitude, professionals, technicians, associate professionals, and service workers, shop and sales workers, crafts, and machine operators, and assemblers. Over a period of almost two decades, the occupational structure of the labor force has changed dramatically.

Table 10: Occupational Distribution of Employed Women; 1993 and 2001

(unit: \%)

\begin{tabular}{|l|c|c|c|}
\hline \multicolumn{1}{|c|}{ Classification } & $\mathbf{1 9 9 3}$ & $\mathbf{2 0 0 1}$ & Change rate \\
\hline Legislators, Senior Official \& Managers & 2.7 & 2.6 & -0.1 \\
\hline Professionals, Technicians \& Associate Professionals & 12.3 & 16.2 & 3.9 \\
\hline Clerks & 12.5 & 11.8 & -0.7 \\
\hline Service Workers \& Shop \& Sales Workers & 20.9 & 26.5 & 5.6 \\
\hline Skilled Agricultural \& Fishery Workers & 13.2 & 9.7 & -3.5 \\
\hline Crafts \& Machine Operators \& Assemblers & 27.3 & 23.0 & -4.3 \\
\hline Elementary Occupations & 11.0 & 10.2 & -0.8 \\
\hline
\end{tabular}

Source: Ministry of Labor (1994, 1998, 2002), Survey Report on Wage Structure.

Note: Author calculation from Ministry of Labor data.

As expected, agricultural occupations declined in importance, while the growth of industrial occupations could also have been anticipated. The proportion of the labor force engaged as service workers, shop and sales workers, also increased though at different rates. Gender segregation in the labor market is high, and most women 
work in a few female-dominated occupations. As in most western countries, women work in white-collar occupations and thus enjoy relatively high prestige, but low income. About half of all employed women work in the public sector. The public sector in Korea is of special importance for female employment. It is comprised mainly of social services, and most female-type occupations (for example, teaching, nursing, social work) are concentrated in this sector. The Korea public sector is characterized by high stability of employment and a high level of professionalism. It is also the sector in which labor laws, especially those concerning women's work, are most strictly observed. In a similar way, women and men tend to be concentrated in different occupations.

The biggest changes in women's labor force participation in recent decades has been in careers that were nontraditional for women in the past. In 1993 females accounted for only 12.3 percent of professionals, technicians and associate professionals; by 2001 this figure had grown to 16.2 percent and females comprised 2.6 percent of legislators, senior officials, and managers. But despite their breakthrough in professional occupations and in management, women are only slowly moving to the top. This has been taken by labor market segmentation theories as supporting their theory of human capital in segregated markets, a separate market for each gender (Bergmann, 1986). According to this approach, women are largely confined to "secondary sector" jobs where wages are low and turnover is high. Lee (1999) found that gender differences in occupations are due to differences in preferences and to differences in employer selection. By employment status, male workers maintained their status before and after the IMF economic crisis. However, among female workers, the proportion of regular (permanent) workers declined (from 37 percent to 32 percent), while daily female workers' share rose substantially (from 16 percent to 21 percent), suggesting that some of the former regular or temporary female workers might have shifted their employment status to daily workers By occupation, while male workers increased in administration, service, and sales occupations, female workers employed in these occupations declined sharply, again implying that there was a certain degree of substitution between male and female workers.

In Korea, the occupational distribution of women employed in general public administration at the Federal, State and local level is fairly compressed and segmented, although there are positive trends emerging in both cases. In the Federal government, while low-paid clerical jobs continue to be the largest single source of employment for women, their relative importance has been reduced, and the weight of professional, administrative and technical categories has increased (Ministry of Health and Social Affairs, 1999); the traditional over-representation of women in administrative support jobs. In contrast to other countries, however, there seems to be a relatively high representation of women in professional and technical jobs. Although true comparisons are impossible to make, American women seem also to be less compressed in the lower ranks of the public sector than in other countries. In 1998 the average grade for women in the federal government was seven which compares to an average grade of 10.1 for men. Horizontal occupational segregation has also persisted over the last decade. The bulk $(75 \%)$ of female employees (non-civil servants) in the public sector continued to work as either office employees (senior officials, secretaries, typists, and clerical assistants) or in blue collar workers. In terms of skilled occupations, however, there have been some improvements. The relative share of women has increased (albeit from a low base level) in a number of occupations, including engineers and chemists from 3 percent in 1990 to almost 9 percent in 1997, technicians from 16 to 23 percent, legal professions from 13 to 26 percent, and physicians from 38 to 50 percent (U.S. Department of Labor, 1999).

\section{Unemployment}

One of the noticeable changes between pre-(1997) and post-(1998) economic crisis periods was the acutely increasing unemployment rate from 2.6 percent to 6.8 percent. This increase was more dramatic among males, from 2.8 percent to 7.6 percent, than among females, from 2.3 percent to 5.6 percent during the same period. One can argue that although unemployment rates were higher among male workers, female workers also suffered sharply (National Statistical Office, 1999).

The unemployment rate for women and men is a good indicator of gender discrimination in the labor market. Table 11 shows that unemployment rates are higher for workers with college and high school education. More education has always reduced the probability of being unemployed. And, it has become an increasingly important criterion for job market success over time. Table 11 shows the unemployment rates by educational attainment level for the 25-64 year-old age group between 1980 and 2001. During the period 1980 to 1998, the 
overall unemployment rate of female students in middle and high school was less than that of male students. However, for college-educated workers, women had higher unemployment rates than men during the same period (National Statistical Office, 1999,2002). A very large proportion of female junior college and college graduates are still looking for jobs one month after graduation, and these proportions are much higher for females than males. This may help explain their relatively low labor force participation rates. College-educated women may drop out of the paid labor force because they cannot find jobs.

As Table 11 shows, educated people are much more likely to be unemployed than less educated people. In terms of unemployment differences between males and females, the male unemployment rate was much higher in upper secondary education level than for any other education level. However, at the female university education level, unemployed rates were much higher than for any other educational level.

Table 11: Unemployment Rates by Educational Attainment Level for 25-64 year-old, 1980-2001

\begin{tabular}{|c|c|c|c|c|c|c|c|c|c|}
\hline \multirow{2}{*}{ Year } & \multicolumn{3}{|c|}{$\begin{array}{c}\text { Below secondary } \\
\text { Education }\end{array}$} & \multicolumn{3}{c|}{$\begin{array}{c}\text { Upper secondary } \\
\text { Education }\end{array}$} & \multicolumn{3}{c|}{$\begin{array}{c}\text { University level } \\
\text { Education }\end{array}$} \\
\cline { 2 - 12 } & Male & Female & Total & Male & Female & Total & Male & Female & Total \\
\hline $\mathbf{1 9 8 0}$ & 3.8 & 2.0 & 2.7 & 9.3 & 10.7 & 7.8 & 6.2 & 9.2 & 9.2 \\
\hline $\mathbf{1 9 8 5}$ & 2.4 & 0.9 & 1.5 & 5.9 & 5.0 & 5.0 & 6.6 & 10.1 & 10.1 \\
\hline $\mathbf{1 9 9 0}$ & 1.1 & 0.6 & 0.7 & 3.4 & 3.1 & 2.6 & 4.4 & 5.3 & 5.3 \\
\hline $\mathbf{1 9 9 5}$ & 1.1 & 0.6 & 0.7 & 2.5 & 2.4 & 2.1 & 2.7 & 3.4 & 3.3 \\
\hline $\mathbf{1 9 9 6}$ & 1.1 & 0.7 & 0.7 & 2.5 & 2.1 & 2.1 & 2.6 & 2.8 & 2.9 \\
\hline $\mathbf{1 9 9 7}$ & 1.5 & 1.0 & 1.0 & 3.3 & 3.3 & 2.8 & 3.0 & 3.7 & 3.7 \\
\hline $\mathbf{1 9 9 8}$ & 5.8 & 3.9 & 4.1 & 8.2 & 7.2 & 8.0 & 5.7 & 6.1 & 6.1 \\
\hline $\mathbf{2 0 0 1}$ & 4.8 & 2.5 & 2.3 & 4.5 & 4.0 & 0.5 & 3.8 & 3.6 & 0.2 \\
\hline
\end{tabular}

Source: National Statistical Office (2002), Social Indicators in Korea.

Notes: Upper secondary education; average of middle and high schools.

Table 12 shows the changing trend in overall wage differentials by occupation distribution level. It is important to note the narrowing of wage differentials by occupation level between 1995 and 1998. In particular, female and male wage differentials of legislators, senior official \& managers and professionals, technicians \& associate professionals are smaller than those of any of the other occupations. However, the wage differential for skilled agricultural \& fishery workers is higher than that for any other occupational category. Since 1995, female and male wage differentials have improved except for skilled agricultural \& fishery workers. However, female and male wage differentials of clerks and skilled agricultural \& fishery workers got worse in 1998.

Table 12: Female and Male Wage Differential Level by Occupational Distribution, 1995-98

(unit: \%)

\begin{tabular}{|l|c|c|c|}
\hline \multicolumn{1}{|c|}{ Classify } & $\mathbf{1 9 9 5}$ & $\mathbf{1 9 9 7}$ & $\mathbf{1 9 9 8}$ \\
\hline Legislators, Senior Official \& Managers & 83.2 & 83.0 & 82.0 \\
\hline Professionals, Technicians \& Associate Professionals & 71.7 & 75.2 & 76.4 \\
\hline Clerks & 60.8 & 74.7 & 64.4 \\
\hline Service workers \& Shop \& Sales Workers & 70.5 & 70.4 & 69.7 \\
\hline Skilled Agricultural \& Fishery Workers & 65.2 & 54.9 & 48.3 \\
\hline Crafts \& Machine Operators \& Assemblers & 57.2 & 62.1 & 62.6 \\
\hline Elementary Occupations & 69.6 & 70.8 & 70.4 \\
\hline
\end{tabular}

Source: Ministry of Labor (various years), Survey Report on Wage Structure. 


\section{Conclusions}

Characteristics of women's well-being are influenced by socioeconomic background, educational attainment, labor force participation, employment, early work experiences, and household conditions. The effect of each of these variables vary in Korea, however, some common relationships appear. Education is positively related to labor force participation, especially in gainful employment. It is also very influential in increasing current occupational status and earnings, as well as motivating women to work outside the home. Parental and community background makes a minimal contribution to current economic status. Their major effects occur at earlier stages, such as the attainment of education and initial entry into the labor force. The steps taken in late adolescence and early adulthood in turn influence current status. Household conditions vary in their effects on current economic behavior. The presence of others in the household increases the likelihood of working outside the home, as well as hours of work.

The presence of children reduces the probability of entering the labor force. However, if the woman is in the labor force, the presence of children increases her chances of working at home. Of the employment characteristics considered, the model is best able to account for variation in occupational status, but it can also explain a fair amount of the variation in other characteristics. In general, education stands as a critical factor in women's efforts to improve their economic status. While education increases participation in the labor force, its effects are more significant in relation to occupational status and earnings. It appears that women's earnings are slowly increasing when compared with men's earnings; women's participation in the labor force continues to move closer and closer to the pattern shown by men, and their educational investment and occupational choices have also become more similar to men's. Women still retain primary responsibility for housework and childcare in most Korean families. However, this pattern has been changing as families respond to rising labor market opportunities for women that increase the opportunity cost of such arrangements. Further, employers' continuing efforts to provide more training and promotion opportunities for women will help to diminish the difference between women's and men's earnings.

Employers also appear to recognize the need to help families balance conflicting needs. The earnings gap should continue to narrow as women work more hours in the week, spend more years at paid work in their lifetimes, continue to increase their educational investment, widen their occupational choices, and equal opportunity becomes a reality.

The first draft of this paper was presented at the 2001 meetings of the International Applied Business Conference (March 14-21, Cancun, Mexico). I'm indebted to anonymous referees and to participants at the 2001 meetings of the International Applied Business Conference for many helpful comments and suggestions on earlier drafts of this paper.

\section{References}

1. Becker, G. S. and Lewis, G.H (1974), Interrelation between Quantity and Quality of Children, in T.W, Schultz (ed), Economics of the Family: Marriage, Children and Human Capital, pp. 81-90, Chicago, University of Chicago Press.

2. Bergmann, B (1986), The Economic Emergence of Women, New York, Free Press.

3. Shapiro, D. and Lois B. Shaw (1983), "Growth in the Labor Force Attachment of Married Women: Accounting for Changes in the 1970s," Southern Economic Journal 50, no 2, pp. 461-43.

4. Easterlin, R. and Crimmins, E (1985), The Fertility Revolution: A Supply-Demand Analysis, Chicago, University of Chicago Press.

5. Lee, Namchul (1999), "Trends in the Female Labour Market of South Korea since 1970," East Asian Review 3, pp. 4157.

6. Lee, Namchul (2000), "Education and Economic Growth in Korea, 1966-1997," Journal of Applied Business Research, 16(4), pp. 24-38.

7. Ministry of Education (various years), Educational Indicators in Korea, Seoul, Korea.

8. Ministry of Health and Social Affairs (1999), Yearbook of Health and Social Statistics, Seoul, Korea.

9. Ministry of Labor (various years), Survey Report on Wage Structure, Seoul, Korea.

10. National Statistic Office (various years), Annual Report on the Vital Statistics. 
11.

12.

13.

14.

15.

16.

17.

18.

19.

20.

21.

22.

, Population \& Housing Census.

, Statistical Yearbook of Education.

Active Population Survey.

Comprehensive Time Series Report on the Economically

OECD (1998), Employment Outlook, Paris, OECD.

, (1997), Annual Report on the Economically Active Population Survey.

Park, S. I. and Park, H.K (1984), The Wage Structure of Korea, Research Series No. 54, Seoul, Korea Development Institute.

United Nations Development Program (1993), Human Development Report, 1993, New York, Oxford University Press.

U.S. Department of Labor (1999), Monthly Labor Review, Washington, DC,: U.S. Government Printing Office. Willis, R. J (1973), "A New Approach to the Economic Theory of Fertility Behavior," Journal of Political Economy, 81, pp. s14-64.

World Bank (1997/2000), World Development Report, Washington, DC,: World Bank.

\section{Appendix}

Market wage equation:

$$
\ln \mathrm{W}_{\mathrm{it}}=\beta \mathrm{Ai}+\xi_{\text {wi, }} \quad \mathrm{i}=1-------n
$$

Reservation wage equation:

$$
\ln \mathrm{W}_{\mathrm{ir}}=\delta \mathrm{B}_{\mathrm{i}}+\xi_{\mathrm{ri}}
$$

where $\mathrm{A}$ and $\mathrm{B}$ are vectors of systematic determinants of the market and reservation wage, respectively. $\xi$ wi, and $\xi$ ri are random deviations with mean zero and there are $n$ individuals. A and B generally contain some of the same variables, some of which may be either endogenous or exogenous.

A labor force participation decision is based on a comparison of the market wage with the reservation wage. Thus, the increase in labor force participation rates can be attributed not only to a rise in the market wage, but also to a decline in female reservation wages. It is likely that an increase in the number of children raises a woman's reservation, and reduces the probability that the woman will work. In fact, if a woman has children under the age of 6 , her probability of working decreases by nearly 20 percent.

A woman will participate in the labor market whenever her potential market wages $\left(\mathrm{W}_{\mathrm{t}}\right)$ exceed her reservation wage $\left(\mathrm{W}_{\mathrm{r}}\right)$. However, if this inequality is not satisfied, she will remain out of the labor force.

Thus $\mathrm{W}_{\mathrm{it}}>\mathrm{W}_{\mathrm{ir}}$ at zero hours of work or equivalently. The probability that individual We will participate in the labor force, $\mathrm{F}_{\mathrm{i}}$ equals the probability that the market wage exceeds the reservation wages:

$F_{i}=\beta_{A i}-\delta B_{i}>\xi_{w i}-\xi_{\text {ri }}$

Since $\xi_{\text {wi, }}$ and $\xi_{\text {ri }}$ are assumed to be two normally distributed random distributions with the mean at zero, one can define $\mathrm{M}=\xi_{\text {ri }}-\xi_{\text {wi }}$ and assume it to be normally distributed with zero and variance $\sigma 2$. The probability of participation in the labor force thus depends on:

$\mathrm{F}_{\mathrm{i}}=\left(\beta \mathrm{A}_{\mathrm{i}}-\delta \mathrm{B}_{\mathrm{i}}\right) / \sigma>(-\mathrm{V} / \sigma)$

where the error terms is the standard deviation. Using a probit procedure I can estimate the parameters $\beta \mathrm{A}_{\mathrm{i}} / \sigma$ and $\delta \mathrm{B}_{\mathrm{i}} / \sigma$. The participation equation $\mathrm{X}$ can be estimated as a reduced-form equation where market wage and reservation wage are replaced by using a direct measurement of the market wage. An individual's potential market wage rate is determined by personal characteristics, such as schooling, work experience, health status, and by characteristics of the labor market in which she is located (rural/urban, region, industrial mix). The shadow price of a married women's time and hence the reservation wage tends to be positively related to the husband's income or other family income, more broadly, household assets, the woman's education level, the number of children, and negatively related to the ages of children. 